\title{
Challenges Facing Black Owned Small and Medium Construction Companies: A Case Study of Nelspruit - Mbombela Municipality, South Africa
}

\author{
${ }^{*}$ Aigbavboa C.O., Thwala W.D. \\ University of Johannesburg, Johannesburg, South Africa \\ *caigbavboa@uj.ac.za
}

\begin{abstract}
The purpose of the paper is to investigate current challenges and problems facing small and medium size contractors (SME) in Mbombela (Nelspruit) - Mpumalanga Province of South Africa. This study was necessitated because the importance of small and medium sized enterprises in national building and economic development is of paramount importance in the South Africa economic debate. The primary data for the study was collected through a structured questionnaire survey which was distributed to Small and medium contractors within grade 1-4 of the South Africa Construction Industry Development Board. The survey results indicated that external factors such as high competition when tendering for construction jobs within the CIDB category is a major challenge the SME's face's in the procurement of work. Also, internal factors such as poor administrative management within the company, lack of skilled professionals and lack of capacity to deliver on certain project were the greatest challenges faced by the construction companies. The scope of this study is only focused on small and medium size contractors in Nelspruit (Mpumalanga province). In addition, the study is not focused on large established contractors in South Africa. The South African construction industry will continue to provide jobs but intervention is needed to develop the SME's contractors who contribute a greatly to the economy.
\end{abstract}

Keywords: Small and medium construction companies, Construction Industry, Mbombela, Nelspruit

\section{Introduction}

Small and medium sized enterprises (SMEs) are considered the engines of growth in developing countries (Mahembe, 2011 - National Credit Regulator document). Mahembe (2011) further informs that the in developed countries, SMEs have historically played a vital role in creating jobs, spurring innovations, and creating new products, and thus contributed to economic vitality and growth. The value of SME sectors are recognised in economies world-wide, irrespective of the economy's developmental stage. They contribute towards economic growth, job creation and social progress which is highly valued; much more, SME's in any sphere of the economy are regarded as an essential element in a successful formula for achieving economic growth (Vosloo, 1994). According to Ahiawodzi and Adade (2012), it is estimated that SMEs account for 70\% of Ghana's gross domestic product (GDP) and 92\% of its businesses. They also make up 97.5\% of formalised businesses in South Africa and 70\% of the manufacturing sector in Nigeria (Abor \& Quartey, 2010).

Previous studies (Thompson, 1991; Ladzani \& Van Vuuren, 2002; Thwala \& Mvubu, 2008) have informed that the development of small, medium and micro-enterprises (SMEs) contributes considerably to job creation (Ladzani \& Van Vuuren, 2002), social stability, economic welfare and the improvement in the quality of people's life across the globe (Ahiawodzi and Adade, 2012). For instance in the United States of America (USA), SMEs have been found to introduced innovative products and services, created new jobs, opened foreign markets, and in the process ignited the USA's economy into a competitive edge in the global economy (Scarborough \& Zimmerer, 1996). Also, in Japan, the SME sector accounts for the bulk of the country's business establishment, providing vital support for employment, regional economies and the extension of the day-to day life (quality of life) of the Japanese people according to the Japanese Ministry of International Trade and Industry (1997). Likewise in Taiwan, Scarborough and Zimmerer (1996) informs that the SMEs sector generates approximately $98 \%$ of the economy's GDP. Although these businesses according to the definition of SME's are relatively small in scale, limited funds, and weak in structure, but they make significant contributions to the national economic prosperity, create innumerable jobs and promote both social and economic stability.

Hence, since the freedom of the South Africa state, the new democratic government has realised the importance of small businesses ventures across all sectors of the country in achieving stable economic growth. In South Africa, SMEs have been identified by the government as a priority in job creation in order 
to solve the protracted unemployment condition facing more than $24.1 \%$ of the current 52.98 million South Africans (Statistics South Africa, 2013). Since SMEs constitutes almost 97.5\% of all formalised businesses in South Africa (Berry et al., 2002), they are a vital tool in the creation of sustainable jobs when they survive the teething years of business dynamics. In South Africa, it is estimated that SMEs contribute between 52\%-57\% to GDP and provide about $61 \%$ of employment (Berry et al., 2002). With particular respect to construction SMEs, they have a crucial role to play in stimulating growth, generating employment and contributing to poverty alleviation; given the weight and the level of investment and financial commitment from the government of South Africa.

SMEs especially those that operate in the construction sector are an important contributor to the economy and are considered a driver for reducing unemployment in South Africa as defined by the National Credit regulation Act; given that the formal sector continues to shed jobs when business transaction are not favourable. Despite their significant importance and contribution to economic growth, SMEs across the whole world, and in South Africa, are still faced with numerous challenges that inhibit entrepreneurial growth (Mahembe, 2011). This has resulted in high rates of business failure; does making South Africa one of the lowest construction SMEs survival regions in the world (Mahembe, 2011; Ahiawodzi and Adade, 2012). Other critical challenges include as defined by other previous scholars in this field include (Ntsika, 1999; Thwala \& Mvubu, 2008; Mahembe, 2011; Ahiawodzi and Adade, 2012): a lack of management skills, finance and obtaining credit, access to markets and developing relationships with customers, appropriate technology and low production capacity, recognition by large companies, government bureaucracy, and support for the role that they play in economic development.

The South African National post-apartheid government being fully aware of the significance of SMEs in economic growth have since produced a framework for SMEs support and growth in the country. The SME sector of the South Africa economy is actively promoted by a number of initiatives such as the National Small Business Act of 1996 which defines SMEs activates in the country and likewise provides for the establishment of the National Small Business Council and the Ntsika Enterprise Promotion Agency (Ntsika) - (Ntsika, 1999; Republic of South Africa - National Small Business Act, 2004). Also, bodies like Khula Enterprise Finance was set up with a mandate to improve the SME sector's access to finance, primarily through the provision of 'wholesale finance' or guarantees to retail financial intermediaries, which, in turn, finance the provision of 'wholesale finance' or guarantees to retail financial intermediaries, which, in turn, finance's the SME sector. Another initiative of the post-apartheid government is creation of the Skills Development programme, which was launched by the government in 1998. Through this initiative, SMEs are able to obtain assistance with two of the challenges that they face most as research has revealed (Thwala \& Mvubu, 2008), i.e. "a lack of management skills" and "developing relationships with customers". This is based on the conviction that improved managerial skills leads to improved productivity and efficiency; and therefore to a more stable organisation and country and increased profits and economic growth. Furthermore, on the creation of initiatives to advance the contribution of small business, the South Africa Construction Industry Development Board (CIDB) when created, was mandated to carryout SME contractor's development as a paramount aspect of their responsibilities. Despite the expanse level of government involvement in the support and development of construction SME, their still remains a high level of issues hindering their survival. Hence, this paper investigates the current challenges and problems facing construction SMEs in Nelspruit- Mpumalanga Province of South Africa. This study was necessitated because the importance of small and medium sized enterprises in national building and economic development is of paramount importance in the South Africa economic debate. The paper begins with a discussion about the general situation of SMEs in Africa, followed by analysis of construction SMEs; thereafter the study area is discussed before the method adopted for the study is presented. This is further followed by the presentation of the research findings and discussion of the results. Lastly, conclusions and recommendations are drawn for the study.

\section{SME Sector in South Africa}

Whilst the importance of the SME sector is recognised internationally, defining an SME is a challenging task regardless of the sector and country they operate, as every country has its own definition (Mahembe, 2011). For instance, Storey (1994) informs that there is no single, uniformly accepted definition of small firms. However, Meghana, Beck \& Demirgüc-Kunt (2003) informs that firms differ in their levels of capitalisation, sales and employment. Thus, definitions which have used the measures of size such as number of employees, turnover, profitability and net worth when applied to one sector might lead to all 
firms being classified as small, while the same size conceptualization definition when applied to a different sector might lead to a different result (OECD, 1997; 2000).

Meghana, Beck \& Demirgüc-Kunt (2003) and Schneider, (2003) states that SMEs are a very heterogeneous group, and they are found in a wide array of business activities, ranging from the single artisan producing agricultural implements for the village market, the coffee shop at the corner, the internet café in a small town, electrical sub-contracting firms, plumbing firms to a small sophisticated engineering or software firm selling in overseas markets and a medium-sized automotive parts manufacturer selling to multinational automakers in the domestic and foreign markets. The owners may or may not be poor; the firms operate in very different markets (urban, rural, local, national, regional and international); embody different levels of skills, capital, sophistication and growth orientation, and may be in the formal or the informal economy (Hallberg, 2001; Meghana, Beck \& Demirgüc-Kunt, 2003; Schneider, 2003).

According to Mahembe (2011), SME definitions can be broadly categorised into two: "economic" and "statistical" definitions. Under the economic definition, a firm is regarded as small if it meets the following three criteria: it has a relatively small share of their market place; it is managed by owners, or part owners, in a personalised way and not through the medium of a formalised management structure; and it is independent in that it is not part of a larger enterprise. Whilst the "statistical" definition, on the other hand, is used in three main areas: quantifying the size of the small firm sector and its contribution to GDP, employment and exports; comparing the extent to which the small firm sector's economic contribution has changed over time; and in a cross country comparison of the small firms' economic contributions. These definitions, however, have a number of weaknesses. For example, the economic definition, which states that a small business is managed by its owners or part owners in a personalised way and not through the medium of a formal management structure, is incompatible with its statistical definition of a small manufacturing firm which might have up to 200 employees. These definitions in some way are necessary, but are not sufficient for an understanding of a sector where the realities are not only complex, but also dynamic.

According to the South Africa National Small Business Act 102 of 1996, SMEs are defined as separate and distinct business entities in any sector of the economy managed by one owner or more. These include cooperative enterprises and non-governmental organizations, as well as branches or subsidiaries if any (Rwigema \& Venter, 2004). However, the South African government has defined the SME sector according to various factors namely, ownership, employment size and formality with various classifications. The most widely used framework in South Africa is the definition of the National Small Business Act 102 of 1996, which defines five categories of businesses in South Africa. The definition uses the number of employees (the most common mode of definition) per enterprise size category combined with the annual turnover categories, the gross assets excluding fixed property. The definitions for the various enterprise categories are given as follows (Republic of South Africa - White paper on national strategy for the development and promotion of small business in South Africa, 1995):

Survivalist enterprise: The income generated is less than the minimum income standard or the poverty line. This category is considered pre-entrepreneurial, and includes hawkers, vendors and subsistence farmers. (In practice, survivalist enterprises are often categorised as part of the micro-enterprise sector).

Micro enterprise: The turnover is less than the VAT registration limit (that is, R150 000 per year). These enterprises usually lack formality in terms of registration. They include, for example, spaza shops, minibus taxis and household industries. They employ no more than 5 people.

Very small enterprise: These are enterprises employing fewer than 10 paid employees, except mining, electricity, manufacturing and construction sectors, in which the figure is 20 employees. These enterprises operate in the formal market and have access to technology.

Small enterprise: The upper limit is 50 employees. Small enterprises are generally more established than very small enterprises and exhibit more complex business practices.

Medium enterprise: The maximum number of employees is 100 , or 200 for the mining, electricity, manufacturing and construction sectors. These enterprises are often characterised by the decentralisation of power to an additional management layer.

The current study adopted the small and medium enterprise classification as a uniform definition which assisted in the process of data collection.

SME construction companies: According to Adendorff, Appels \& Botha, (2011), the development and growth of construction SMEs are important for all countries, as a strong construction SME base has the 
capacity to produce a high-quality infrastructure for the country. Likewise, Ofori (2009) informs that the development and growth of construction SMEs are important issues for all countries, as a strong SME base has the ability to produce quality and timeously delivery of infrastructure for the country. Additionally, Ofori (2009) states that construction SMEs also kindle economic activity in other sectors of the economy. However, Dlungwana et al. (2002) informs that construction SMEs face many problems when dealing with construction projects, and, as a result, poor performance and poor quality of work are unfortunately prevalent among SMEs in the construction industry.

The South African construction industry has experienced a considerable growth and success, particularly as a result of the government's considerable infrastructural spending which was extended to the 2010 FIFA World Cup and has been further extended in the current 2014 national budget in order to stimulate growth in the economy because of the multiplier's effect that comes from the construction industry. The construction industry contribution to South Africa's GDP is estimated to be 13\% between 2007 and 2012 (Stats SA, 2013). The industry was one of only a few sectors to have increased its contributions to GDP by a further 2.3\% during the third quarter estimate of 2013. However, the growth in the industry cannot be considered in terms of the number of contractors moving from the lower to the upper grades of the CIDB register of contractors; as it is recorded that about $95 \%$ of all registered contractors that can be categorised as SMEs which fall within level 1-4 of the Construction Industry Development Board's classification system as indicated in Table 1 (CIDB, 2004; 2010).

The 2004 CIDB Regulations, (CIDB Act, 2000) restricts construction SMEs in the lowest level of the CIDB's National Register of Contractors with regards to the size of the projects for which they may tender (CIDB Regulations, 2004). Construction SMEs listed in grade one to four, while grade is the entry and lowest level, may only tender for projects up to a value of R200.000. Whilst contractors in grade nine may tender for an unlimited value (CIDB, 2004). Hence, the CIDB has continually expressed concern over the high concentration of lower level contractors that fail to move up the grades (Cameron, 2007). The situation is present in all provinces of South Africa; the number of grade-one contractors is extremely high at $95 \%$ of all registered contractors. South African construction SMEs faces many problems when dealing with construction projects as common to other SME types which results in, poor project performance and poor quality of work in the execution of construction projects the industry (Dlungwana et al., 2002). Since clients desire value for money for commissioned projects, Barry and Sebone (2009) and Adendorff, Appels \& Botha (2011) infers that when construction SMEs consistently deliver poor quality projects, this in turn, lead to the low success rate of SMEs. Likewise, Ofori (2009) informs that SMEs in all sectors faces challenges but the unique ones to construction SMEs include which greatly hinders their growth and development include: contractor's low level of bargaining power during the tendering process; projectbased nature of work which implies discontinuity and mode of work done payment by the client (client only pays for work that has been completed) which hinders their effective cash flow to executive the job.

Mbombela as a study area: Mbombela, the capital of the Mpumalanga province, is a vibrant, sub-tropical city that combines a rich history with scores of wildlife and nature adventure activities and attractions. This dynamic city is not only the gateway to Kruger National Park, but is home to superb botanical gardens, and great shopping. Mbombela Local Municipality (MLM) has a well-established economy consistently achieving growth rates higher than the South Africa and the Mpumalanga economics in most sectors (Mbombela Local Municipality, 2014). It is well positioned to take advantage of strong international, national and regional linkages and become an active role-player in the Southern Africa economy. Nelspruit is the seat of the Mpumalanga provincial government, and the foremost industrial, commercial, retail and services centre for the region, including Mozambique and Swaziland and is positioned to enjoy the economic benefits of the 2010 FIFA World Cup. MLM is endowed with areas like Nelspruit which is the capital of the MLM. MLM is currently involved in the following big projects, the development of the Maputo development Corridor project, the Mpumalanga Investment initiative, the Transfronteir Park, and the Mpumalanga International airport (Mbombela Local Municipality, 2014). MLM's key strategic objectives are to provide water and sanitation and other basic services to its communities. In the rendering of these services is where the jobs of the SMEs are needed as they assist with the speedy and timely delivery of the infrastructure services. Hence, the need to assess their most current challenges and recommend ways to ensure their growth in order to ensure their development which thus contribute to the development goals of Mbombela. 


\section{Methodology}

The research made use of the quantitative research method adopting the use of structured questionnaires. Targeted participants of this study were small and medium contracting firms in the Mbombela municipality region within a grading of 1-4 as classified by the South Africa Construction Industry Development Board. The firms in these categories are only allow to bid and execute construction works between the value of R200 000 to R4 000000 . The respondents in the firms were the business owners, project managers, construction managers and quantity surveyors were they were available. Based on the quantitative methodology of simply random sampling, all SMEs in on CIDB grade 1-4 in Mbombela had an equal chance to be drawn and participate in the survey. Out of the 60 questionnaires sent out, 45 were received back representing a $75 \%$ response rate. The data presentation and analysis made use of frequency distributions and percentages of all the respondents. The research was conducted between the months of June to August, 2013.

Mean Item Score index (MIS): A 5-point Likert type scale was used to determine the current challenges faced by SME contractors in Mbombela (Nelspruit). The adopted scale read as follows, 1=strongly disagree, $2=$ Disagree, $3=$ Neutral, $4=$ Agree, and $5=$ strongly agree. The five-point scale was transformed to mean item scores indices (MIS) for each of the factors identified from literature as potential sources of survivl for SMME firms which were assessed by the respondents. The indices were then used to determine the rank of each item. These rankings made it possible to cross compare the relative importance of the items as perceived by the respondents. The MIS was based on the previous studies as conducted by Aibinu and Jagboro (2002) and Kometa et al. (1995) that used the 'MIS index' method in rating their study criterions. This method was also adopted to analyze the data collected from the questionnaire survey.

The computation of the relative importance indices (RII) was calculated from the total of all weighted responses and then relating it to the total responses on a particular aspect. This was based on the principle that respondents' scores on all the selected criteria, considered together, are the empirically determined indices of relative importance. The index of RII of a particular factor is the sum of the respondents' actual scores (on the 5-point scale) given by all the respondents' as a proportion of the sum of all maximum possible scores on the 5-point scale that all the respondents could give to that criterion. Weighting were assigned to each responses ranging from one to five for the responses of 'strongly disagree' to 'strongly agree'. This is expressed mathematically below in equation 1.0. The relative importance index (RII) was calculated for each item as follows, after Lim and Alum (1995):

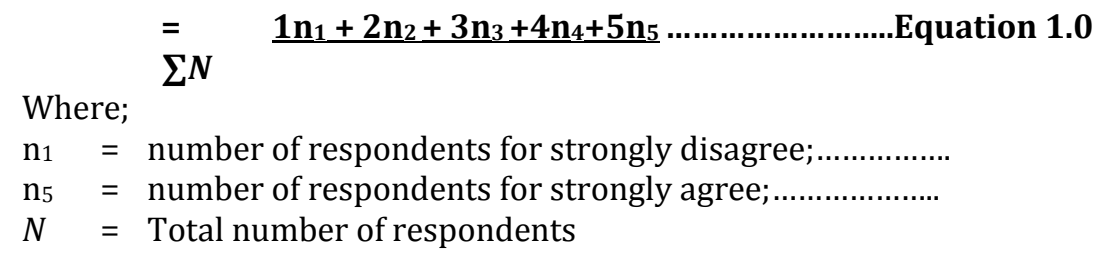

Following the mathematical computations, the criteria are then ranked in descending order of their mean item socre index (from the highest to the lowest). The next section of the article presents the findings of the survey and some discussion.

\section{Findings and Discussion}

Findings from the questionnaire survey relating to the ownership and control of the construction SMEs revealed that $75 \%$ of the respondents were part owners of the business, while $15 \%$ were managing directors' overseeing the activities of the business on behalf of the owners. Further, the survey revealed that the highest educational qualification of the respondents were structured thus: $23 \%$ had grade 12 (Matric, Std 10) as the highest level of education whilst 13\% had certificate form technical colleges, 33\% also had post matric diploma certificate while only $27 \%$ had a Bachelor's degree/ it equivalent. Likewise, when the respondents were asked of a built environment related degree or qualification, it was found that only $20 \%$ of them (of the managing directors') had a Bachelor's degree/ it equivalent whilst the other $80 \%$ (both owners and the acclaimed managing directors managing the business on behalf of the owners) had degree from other disciplines not construction related. This finding thus reveals that construction is perceived just as another business venture of interest. It is generally alleged that running a building or construction business involves quoting for work, managing staff, contracts, and growing a customer base, 
while balancing the books and more. However, there is more to it than meets the eye because of the complexity of the construction industry. This is one of the major reason SMEs are unable to move beyond their initial categories of registration; as most of the owners and managers of the SME firms do not have the technical know-how to run the business.

Furthermore, the survey revealed that the all respondents' cumulative years of experience was 165 years; with the lowest being 2 years while the highest was 12 years. Also, findings relating to the current project execution of the SMEs revealed that $67 \%$ were handling between $2-4$ projects while $22 \%$ were currently handling one project each with some stating that they had just completed between 1-3 projects each within the calendar year of the research. However, $11 \%$ informed that they have not had any major (meaningful) job in the last 6 months. Findings relating to the value of the projects they were currently handing revealed that $60 \%$ of the SMEs were handling projects worth between R100 000 - R500 000; whilst $25 \%$ were handling projects worth R500 $000-\mathrm{R} 1000000$ and the rest $15 \%$ were handling projects worth more than R1 000000 . This aspect of the survey coincides with the cidb job execution classification for SMEs firms registered in grade 1-4.

Table 1: Challenges facing Black Owner SMEs in South Africa

\begin{tabular}{lll}
\hline Challenges facing SMEs & Mean Item Score & Ranking \\
\hline Lack of managerial skills and planning & 2.13 & 1 \\
Lack of access to work opportunities & 2.13 & 1 \\
Prolonged economic recession & 2.00 & 2 \\
Lack of financial skills & 1.94 & 3 \\
Competition & 1.94 & 3 \\
Incompetent employees & 1.94 & 3 \\
Lack of business skills & 1.81 & 4 \\
Lack of sound technical skills & 1.81 & 4 \\
Lack of pricing skills & 1.69 & 5 \\
Loss of skilled personnel & 1.63 & 6 \\
Shortage of skilled employees & 1.31 & 7 \\
\hline
\end{tabular}

Based on the ranking (R) of the weighted average of the mean item score (MIS) for the challenges facing black owned SMEs, the findings revealed that the most critical challeges facing black owned SMEs are: lack of managerial skills and planning / lack of access to work opportunities both having an MIS=2.13 and were ranked (R) first. Also, the prolonged economic recession as faced by South during the global economic crisis was rate second (MIS=2.00; $\mathrm{R}=2$ ). Other chanllenges include: lack of financial skills (MIS=1.94; $\mathrm{R}=3$ ), compeptition, incomepte skilled employees accessed to have the same level of effect (MIS=1.94; $\mathrm{R}=3$ ), business skills and lack of sound technical skills (MIS=1.81; $\mathrm{R}=4$ ), pricing skills (MIS=1.69; R=5), loss of skilled personnels ( $M I S=1.63 ; \mathrm{R}=6$ ) and the least rated chanllenge was shortages of skill employees (MIS=1.31; $\mathrm{R}=7$ ).

These findings concurs with the work of Driver et al. (2001), where it was found that South African SME entrepreneurs often lack experience such as: lack of managerial skills and planning, lack of access to work opportunity, and financial skills thereby hindering them from successfully pursuing business opportunities and hindering their growth. Also, the findings are in agreement with Deakins \& Freel (2003) who found that the difference between SMEs firms grow and adapt to business conditions and those that do not, lies in the management skills of the entrepreneur and too often the importance of these management skills are ignored through concentration on marketing or the personal characteristics of the entrepreneur. Likewise, Scott (2011) informs that maintaining good relationship is a major critical success factors for the survival of any firms, and also that contractors can benefit from better relationships with their clients through a number of different ways, such as: Repeat business, work continuality, and improved profitability. 


\section{Conclusion}

The paper set out to explore the current challenges and problems facing small and medium size contractors (SME) in Mbombela (Nelspruit) - Mpumalanga Province of South Africa. An all-inclusive international and South African literature study was carried out which identified variables that were validated through a structured questionnaire survey conducted amongst SMEs business owners, project managers, construction managers and quantity surveyors in the research geographical area. The empirical study, although based on a relatively small sample of SME stakeholders in Nelspruit, revealed that the factors which had been identified in the literature as contributory to SME's challenges were also found in the study area. Hence, it was found that the most critical current challenges facing construction SME's are: lack of managerial skills and planning / lack of access to work opportunities, prolonged economic recession, lack of financial skills, competition, in compete skilled employees, business skills, lack of sound technical skills and pricing skills. Although the sample used was limited, but the findings are indicative of the current challenges facing construction SME's in Nelspruit, Mbombela, Mpumalanga Province of South Africa. In terms of reliability of the methodology adopted; when the procedure is followed in a bigger and more diversed sample, findings would justify the current study. Hence, the results revealed in this study gives valuable insights for the improvement of construction SMEs in the study area. It is therefore recommended that the following should be adopted in order to significantly reduce the high failure rate of construction SMEs in the Mpumalanga Province of South Africa. Therefore, construction SMEs firms should invest more in the training of their managerial employee and undertake proper planning of projects before embarking on site construction. Also, SMEs should employ the services of better qualified personnel's in their firm as well having construction mentors which can assist to eliminate some of the factors that are currently challenges to them thus reducing construction SME failures in the research focus area.

\section{References}

Abor, J. \& Quartey, P. (2010). Issues in SME Development in Ghana and South Africa. International Research Journal of finance and Economics, 39(6), 215-228

Adendorff, C., Appels, G. \& Botha, B. (2011). Strategic management: An Eastern Cape construction SME case study. Acta Structilia, 18(2), 40-63.

Ahiawodzi, A. K. \& Adade, T. C. (2012). Access to credit and growth of small and medium scale enterprises in the Ho Municipality of Ghana. British Journal of Economics, Finance and Management Sciences, 6(2), 34-51.

Aibinu, A. A. \& Jagboro, G. O. (2002). The effects of construction delays on project delivery in Nigerian construction industry. International Journal of Project Management, 20, 593-599.

Barry, M. L. \& Sebone, M. F. (2009). Towards determining critical success factors for SME electrical contractors in the construction industry in South Africa. South African Journal of Industrial Engineering, 20(1), 185-195.

Berry, A., Von Blottnitz, M., Cassim, R., Kesper, A., Rajaratnam, B. \& van Seventer, D. E. (2002). The Economics of SMMEs in South Africa, Trade and Industrial Policy Strategies, Johannesburg, South Africa

Cameron, L. (2007). Too few contractors moving up the grades. Engineering News [online]. Available from: <http://www.engineeringnews.co.za/article/too-few-contractorsmoving-up-the-grades2007-11-02> [Accessed: 18 January, 2014].

CIDB (Construction Industry Development Board). (2004). Regulations. Department of Public Works of South Africa [Online]. Available from: <http://www.cidb.org.za/Documents/KC/cidb_Publications/Leg_Regs/other_leg_regs/leg_regs_r egulation_amended_14nov08.pdf> [Accessed: 10 March, 2014].

CIDB (Construction Industry Development Board). (2010). National Register of Contractors. [Online]. Available from: <http://www.cidb. org.za/Reports/public/default.aspx> [Accessed: 9 January, 2014].

Deakins, D. \& Freel, M. (2003). Entrepreneurship and small firms, in K. Reade \& N. Jacobs (eds) The Entrepreneur Concepts and Evidence, McGraw-Hill Education, UK, pp. 3-8.

Dlungwana, S., Noyana, C., Nxumalo, X. H., Rwelamila, P. D. \& Van Huysteen, S. (2002). Development and implementation of the South African Construction Excellence Model (SACEM). International Conference on Construction in the 21 Century: Challenges and opportunities in Management and Technology 25-26 April 2002, Miami, Florida, USA. [Online] Available from: 
<http://researchspace.csir.co.za/dspace/bitstream/10204/2976/1/Dlungwana_2002.pdf>

[Accessed: 21 February 2014].

Driver, A., Wod, E., Segal, N. \& Herrington, M. (2001). Global Entrepreneurship Monitor: 2001 South Africa Executive Report, Graduate School of Business, University of Cape, Town.

Hallberg, K. (2001). A Market-Oriented Strategy for Small and Medium-Scale Enterprises', IFC Discussion Paper \#48.

Kometa, S. T., Olomolaiye, P. O. \& Harris, F. C. (1995). Attributes of UK construction clients influencing project consultants' performance. Construction Management and Economics, 12(5), 433-443.

Ladzani, W.M. \& VAN Vuuren, J.J. (2002). Entrepreneurship Training for Emerging SMEs in South Africa. Journal of Small Business Management, 40, 154-161.

Lim, E. C. \& Alum, J. (1995). Construction productivity: issues encountered by contractors in Singapore. International Journal of Project Management, 13(1), 51-8.

Mahembe, E. (2011). Literature Review on Small and Medium Enterprises' Access to Credit and Support in South Africa. Underhill Corporate Solutions. National Credit Regulator (NCR): Pretoria, South Africa.

Mbombela Local Municipality. (2014). Welcome to Mbombela City. Available online: http://www.mbombela.gov.za/index.html (Accessed, 23 January, 2014).

Meghana, A., Beck, T and Demirgüç-Kunt, A. (2003). Small and Medium Enterprises across the Globe: A New Database. World Bank mimeo.

Ministry of International Trade and Industry (MITI). (1997). White Paper on Small and Medium enterprises in Japan.

Ntsika. (1999). State of Small Business in South Africa, SARB Quarterly Bulletins; and Stats SA Releases, South Africa.

OECD. (1997). Globalization and Small and Medium Enterprises, V. 1: Synthesis Report, Paris

OECD. (2000). Small and Medium-sized Enterprises: Local Strength, Global Reach, Policy Brief, Paris, June.

Ofori, G. (2009). Construction SMME development. Isiza. Issue 6 [Online]. Available from: <http://www.isiza.co.za/features/cidb/982388.htm> [Accessed: 12 March, 2014].

Republic of South Africa. (2004). National Small Business Act, no. 102 of 1996. Government Gazette. 377, 17612.

Republic of South Africa. (1995). White paper on national strategy for the development and promotion of small business in South Africa. Government Gazette, 357, 16317.

Rwigema, H. \& Venter, R. (2004). Advanced Entrepreneurship. Oxford University Press Southern Africa, Cape Town.

Scarborough, N. M. \& Zimmerer, T. W. (1996). Entrepreneurship and New Venture Formation, Upper Saddle River, New Jersey: Prentice Hall Publishing Company.

Schneider, F. (2003). The Size and Development of the Shadow Economies and Shadow Economy Labor Force of 22 Transition and 21 OECD Countries: What Do We Really Know? in Boyan Belev, editor, The Informal Economy in the EU Access Countries: Size, Scope, Trends and Challenges to the Process of EU Enlargement, Center for Study of Democracy, p. 23-61, Sofia.

Scott, B. M. (2011). Survival strategies of services subcontracting firms in an economic downturn, A Report for Industry Project CONS 7819, Unitec New Zealand.

Storey, D. (1994). Understanding the small business. London: Thomson

Thompson, K. (1991). Facing an uphill battle. B.E. Special Report on Small Business. Black Enterprise, 19, 22- 4 .

Thwala, W. D. \& Mvubu, M. (2008). Current challenges and problems facing small and medium size contractors in Swaziland. African Journal of Business Management, 2, 093-098.

Vosloo, W.B. (1994). Entrepreneurship and Economic Growth 1st Ed. Pretoria: HSRC Publishers. 